\title{
Anti-oxidant and Selective Anti-proliferative Effects of the Total Cornicabra Olive Polyphenols on Human Gastric MKN45 Cells
}

\author{
Alireza Amiri Nowdijeh ${ }^{1}$, Mohammad Amin Moosavi ${ }^{2}$, Simzar Hosseinzadeh ${ }^{3}$, Masoud Soleimani ${ }^{4,5}$, \\ Farzaneh Sabouni ${ }^{2}$, Mehdi Hosseini-Mazinani ${ }^{1, *}$ \\ ${ }^{1}$ Department of Plant Molecular Biotechnology, National Institute of Genetic Engineering and Biotechnology, Tehran, \\ Iran \\ ${ }^{2}$ Department of Molecular Medicine, National Institute of Genetic Engineering and Biotechnology, Tehran, Iran \\ ${ }^{3}$ School of Advanced Technologies of Medical Sciences, Shahid Beheshti University of Medical Science, Tehran, Iran \\ ${ }^{4}$ Department of Hematology, Faculty of Medical Sciences, Tarbiat Modares University, 14115-331, Tehran, Iran \\ ${ }^{5}$ Department of Stem Cell Biology, Stem Cell Technology Research Center, Tehran, Iran
}

* Corresponding author: Mehdi Hosseini-Mazinani, Department of Plant Molecular Biotechnology, National Institute of Genetic Engineering and Biotechnology, Tehran, Iran. Phone: +98 21 44787345; E-mail: hosseini@nigeb.ac.ir

\begin{abstract}
Background: According to the epidemiological studies, consuming olive products can decrease the incidence of the different types of cancers mostly due to the high anti-oxidant properties of their polyphenolic compounds.

Objectives: To evaluate the anti-oxidant and anti-proliferative potentials of the olive fruits total polyphenols on the gastric adenocarcinoma MKN45 cells in comparison to the normal $\mathrm{Hu} 02$ cells.

Materials and Methods: The total phenolic content of the olive fruits and radical scavenging activity were determined by Folin and 2,2-diphenyl-1-picrylhydrazyl (DPPH) tests respectively. MTT assay was performed for the evaluation of the cell viability. Intracellular reactive oxygen species (ROS) level was measured using DCFH-DA. Statistical analysis was performed using SPSS 16 statistical software.

Results: Treatment of the MKN45 cells with the phenolic compounds extracted from olive fruits decreased growth and viability of the cells in a dose- and time-dependent manner. In addition, treatment of the MKN45 cells with a combination of the phenolic compounds extracts and cytarabine further decreased cell compared to monotherapy of the cells with each compound alone. Mechanistically, we showed that the anti-cancer effects of the olive polyphenols in the MKN45 cells are mediated through depletion of ROS. Similarly, polyphenolic extracts were found to decrease ROS level in the normal cells at the concentrations of 500 and $1000 \mu \mathrm{g} \cdot \mathrm{mL}^{-1}$ and short treatment times $(6 \mathrm{~h})$, but the viability of these cells did not significantly change. At high concentrations $\left(2000 \mu \mathrm{g} \cdot \mathrm{mL}^{-1}\right)$ of the phenolic extracts or at longer times of incubation $(12 \mathrm{~h})$, however, both ROS levels and the viability of the cells were significantly decreased in the normal cells.

Conclusions: The olive fruits polyphenolic extract modulates ROS levels and selectively targets cancerous cells at low concentrations. Also, the effects of cytarabine could be potentiated by the olive fruits polyphenols. Thus, for a combined protocol of cancer cell therapy, olive fruit polyphenolic compound could be proposed as a proper candidate.
\end{abstract}

Keywords: Cytarabine; Olea; Sunphenon; Reactive Oxygen Species; Stomach Neoplasms

\section{Background}

Olive oil obtained from the olive fruit is a source of polyphenolic compounds; a mixture of organic compounds that olive plant produces in order to confront biotic/abiotic stresses which the plant was continuously exposed in the during of growth and development (1). Recent studies have shown that consuming virgin olive oil with a higher ratio of polyphenols reduces the oxidative damage (2) and is capable of improving various physiological features in the individuals who daily consume virgin olive oil in their diet. Based on epidemiological studies, consuming olive products is associated with the low incidence of a variety of cancers, including leukemia, colorectal carcinoma, and breast cancers (3).

Recent reports indicate that the chemo-preventive ability of the olive oils is mostly related to their high antioxidant properties. It has been recently suggested that the polyphenolic compounds can be used in adjuvant therapy approaches for the cancer treatment $(4,5)$. For example, Menendez et al. showed that olive oil 
polyphenols not only can be used in adjuvant therapy for the killing of tumor cells but also can be utilized for designing a new generation of the drugs (6). The beneficial effects of the olive oil in cancer are mostly through a synergy of the all its major and minor components that can generate a variety of cell responses involved in the cancer prevention and treatment $(7,8)$. In fact, polyphenols modulate oxidative stress in cancer cells through modulation of signal transduction and the expression of specific genes related to the cell proliferation and cell death $(9,10)$. As an evidence, polyphenol compounds trigger apoptotic programmed cell death pathways in human gastric carcinoma cells via manipulation of ROS content of the cancerous cells. Conceptually, the ROS modulating effects of the polyphenols can increase or decrease in basal ROS levels of the cells, proposing a new therapeutic strategy based on pro-oxidant or anti-oxidant therapy, respectively. Due to the difference in the basic ROS levels and oxidative stress status between normal and cancerous cells, these therapeutic approaches are used for the selective targeting of cancerous cells. For example, it has recently been reported that a controlled manipulation of the ROS can selectively target leukemia cells but not normal cells (11). Also, it has been reported that normal cells are less sensitive to the polyphenols compared to cancer cells $(12,13)$.

The incidence of cancer and its mortality rate is rising worldwide (14), and among cancers, gastric cancer is one of the leading cause of cancer death $(15,16)$. A positive growing trend of cancer caused death from stomach cancer (the most common type of cancer in men) toward gastric cancer has been recently reported in several parts of the world (17). Obviously, any effort in finding new anti-cancer drugs and strategies has a high priority in the cancer research.

\section{Objectives}

This study aimed to evaluate anti-oxidant potential of the polyphenolic compound extracted from olive fruits and to study its effects on the growth and viability of the human gastric cancer cell line MKN45 in comparison to the normal $\mathrm{Hu} 02$ cells.

\section{Materials and Methods}

\subsection{Sampling and Preparation of the Total} Polyphenol Extract (TPE)

The olive fruits of Cornicabra variety were collected in the autumn of 2013. Cornicabra is a Mediterranean commercial olive variety that is known as a rich source of polyphenolic compounds (18). The collected fruit samples were immediately frozen in the liquid nitrogen and were transferred to the laboratory. The pulps of the fruits were powdered through grinding in the liquid nitrogen; 3 gr of which was dissolved in $12 \mathrm{~mL}$ of methanol (methanol/H2O, 80\%) and then centrifuged $(2500 \mathrm{rpm})$ at $4{ }^{\circ} \mathrm{C}$ for $20 \mathrm{~min}$. The supernatant was collected as the total/methanolic extract and was freezedried and stored at $-20^{\circ} \mathrm{C}$ before usage. The supernatant was collected and TPE (olive/methanol extract) were obtained and immediately used for Folin and DPPH assessments.

\subsection{Determination of the Total Phenolic Content (TPC)}

The total phenolic content was measured according to the modified Folin-Ciocalteu's reagent method (19). Briefly, the primary methanolic extract was 10 times more diluted using methanol and $30 \mu \mathrm{L}$ of which was mixed with $100 \mu \mathrm{L}$ of the Folin-Ciocalteu's reagent. After mixing for $1 \mathrm{~min}, 300 \mu \mathrm{L}$ of $20 \%(\mathrm{w} / \mathrm{v}$ ) sodium carbonate solution was added and the mixed solution was kept for $2 \mathrm{~h}$ in the dark at room temperature. The absorbance of the reaction mixture was measured at 765 $\mathrm{nm}$. The result was expressed as $\mathrm{mg}$ of Gallic acid equivalent per $\mathrm{ml}$ of the fresh weight (mg GAE.mL fresh weight) for obtaining calibration curve of Gallic acid.

\subsection{Determination of Radical Scavenging Activity} (RSA) of TPE

2,2-diphenyl-1-picrylhydrazyl (DPPH) radical scavenging assay of the sample was carried out according to the standard method with some modifications (20). Several concentrations of each sample were tested and $10-100 \%$ of the free radical scavenging activity was determined. At first, $2.7 \mathrm{~mL}$ methanol was mixed with $0.3 \mathrm{~mL}$ of $0.10 \mathrm{mM} \mathrm{DPPH}$ methanolic solution and then $20 \mu \mathrm{L}$ of the extract was added. After an incubation period for $30 \mathrm{~min}$ at room temperature and dark condition, the absorbance was determined compared to a blank sample at $517 \mathrm{~nm}$ (21). The percentage of DPPH inhibition was calculated as follow:

$\mathrm{DPPH}$ scavenging $\%=(($ Absorbance controlAbsorbance sample)/Absorbance control) $\times 100$

The pure DPPH solution was used as a control group and methanol was used for the baseline correction. The extract concentration that provided $50 \%$ inhibition (EC50 $\mu \mathrm{g} \cdot \mathrm{mL}^{-1}$ ) was calculated from the log-dose inhibition curve regression equation. EC50 values are referred to the lower concentration of the compounds required for the $50 \%$ of the anti-oxidant activity.

\subsection{Cell Culture and Treatment of Cells}

For cell studies, the lyophilized extract was dissolved in PBS and sterilized by filtration $(0.22 \mathrm{~mm})$.The human gastric adenocarcinoma cell line (MKN45) and human fibroblast cell line ( $\mathrm{Hu} 02)$ was obtained from Iranian Biological Resources Center (IBRC) Cell Bank, Tehran, Iran. MKN45 cells were routinely grown in DMEM (Gibco, USA) containing 10\% FBS, 50 冈. $\mathrm{mL}^{-1}$ penicillin and $50 \mu \mathrm{g} \cdot \mathrm{mL}^{-1}$ streptomycin in a humidified incubator at $37^{\circ} \mathrm{C}$ supplied with $5 \% \mathrm{CO}_{2}$. The harvested cells were seeded into 96-well plates $\left(1 \times 10^{4}\right.$ cell.well $\left.^{-1}\right)$. The sterilized extracts were used for the treatment of the cells. After $24 \mathrm{~h}$ of incubation, the cells were treated with 
the different concentration of the olive fruit extracts, Cytarabine $\left(500,1000\right.$, and $\left.2000 \mu \mathrm{g} \cdot \mathrm{mL}^{-1}\right)$; separately or in combination (i.e., different combination of the concentrations:) olive extract + Cytarabine $(250+250$ $\left.\mu \mathrm{g} \cdot \mathrm{mL}^{-1}\right)$, olive extract + Cytarabine $\left(500+500 \mu \mathrm{g} \cdot \mathrm{mL}^{-1}\right.$, and olive extract + Cytarabine $\left(1000+1000 \mu \mathrm{g} . \mathrm{mL}^{-1}\right)$ were used and treatment was carried out for 24,48 , and $72 \mathrm{~h}$.

\subsection{Cell Viability Analysis}

The effect of the olive extract on cell proliferation was evaluated by MTT (3-(4, 5-dimethylthiazol-2-yl)-2, 5diphenyltetrazolium bromide) assay with some modifications as described by Scudiero et al. 1988.

MTT assay and growth inhibition were assessed $24 \mathrm{~h}, 48$ $\mathrm{h}$, and $72 \mathrm{~h}$ after the addition of the extracts and results were reported as the percentage of cell viability of the non-treated cells compared to the control group. Briefly, control and treated cells were collected at different time intervals, then $100 \mu \mathrm{L}$ MTT $\left(100 \mu \mathrm{g} \cdot \mathrm{mL}^{-1}\right)$ was added to each well of 96 -well plates.

Plates were then incubated for $4 \mathrm{~h}$ at $37^{\circ} \mathrm{C}$, then the whole medium was removed and $100 \mu \mathrm{L}$ DMSO was added for solving the formazan crystals. The difference in the purple color between samples was measured at $570 \mathrm{~nm}$ using a plate reader (BioTeck, USA). For each treatment, cell viability was calculated using the below formula:

Viable cells $(\%)=\left(\mathrm{OD}_{\text {treated cells }} / \mathrm{OD}_{\text {control }}\right) \times 100$

\subsection{Measurement of the Intracellular ROS Generation}

The intracellular reactive oxygen species (ROS) level was measured using a cell-permeable fluorescent probe, 2',7'-dichlorofluorescein di-acetate (DCFH-DA) (22). Upon oxidative stress, this probe is cleaved by the nonspecific esterases and forms DCF with the high fluorescent intensity (23). Briefly, cells were seeded into 96-well culture plates and treated with the different concentrations of polyphenol extracts for different time intervals (24). The extracted polyphenol protective capacity against oxidative stress was evaluated through incubation of the cells with a combination of extract plus $\mathrm{H} 2 \mathrm{O} 2$. All treatments were considered for $6 \mathrm{~h}, 12 \mathrm{~h}$ and $24 \mathrm{~h}$. Then, the cells were incubated with DCFH-DA (15 $\mu \mathrm{M}$ in PBS) for $40 \mathrm{~min}$ at $37^{\circ} \mathrm{C}$ in $5 \% \mathrm{CO} 2$. The fluorescence intensity was quantified at $485 / 535 \mathrm{~nm}$ and compared with the fluorescence of the non-treated cells. The corresponding absorbance values were obtained by applying a fluorescent ELISA reader (Synergy H4 hybrid reader - Biotech). The percentage of the intracellular ROS level was calculated as the ratio of the fluorescence of treated cells/fluorescence of nontreated cells, respectively.

\subsection{Statistical Analysis}

The statistical analysis was performed by One-way ANOVA $(P<0.05)$ using SPSS 16 statistical software. The student $t$-test was used for identification of the significant differences. All the analyses were done in triplicates, and each performed in three independent experiments.

\section{Results}

\subsection{In vitro Anti-Oxidant Activity of the Total Phenol Content (TPC)}

At first step of this study, we extracted the total polyphenol from the Cornicabra olive variety to evaluate its anti-oxidant activity. As indicated in Table 1, TPC was $8.4 \pm 0.03 \mathrm{mg} \cdot \mathrm{g}^{-1} \mathrm{GAE} / \mathrm{FWP}$ in the fruit samples which harvested at 150 days after flowering (DAF). In this condition, the percentage of the free radical inhibition was $31.26 \pm 0.04$ and RSA was calculated as $2.5 \pm 0.04 \mathrm{mg} \cdot \mathrm{mL}^{-1}$. According to the results presented in Table 1, a direct relationship between the phenolic content and anti-oxidant capacity of the examined olive extract can be observed.

Table 1. Determining the total phenolic content (TPC), DPPH activity, and radical scavenging activity (RSA) of the methanolic polyphenol-rich Extract derived from Cornicabra olive pulp on 150 days after flowering (DAF). For TPC and RSA, mg.g ${ }^{-1}$ suggests mg garlic acid/g fresh weight of fruit and mg ascorbic acid/g fresh weight of fruit, respectively.

\begin{tabular}{lccc}
\hline Cultivar & TPC $\left(\mathbf{~ m g . g}^{-1}\right)$ & \% of DPPH scavenging & \left.${\text { RSA }\left(\mathbf{m g}^{-1}\right)}^{-1}\right)$ \\
\hline Cornicabra & $8.4 \pm 0.03$ & $31.26 \pm 0.04$ & $2.5 \pm 0.04$ \\
\hline
\end{tabular}

\subsection{Anti-Proliferative Effects of the Olive Polyphenols,} Alone or in Combination with Chemotherapy Agent, on the MKN45 and HuO2 Cells

At next step, the anti-proliferative effects of the polyphenolic extracts from the olive fruits were studied on MKN45 cells (Fig. 1A-C). The results showed a dose- and time-dependent decrease in the viability of cancerous MKN45 cells (Fig. 1A-C). For example, cell viability was reduced by 65,64 and $58 \%$ after $24 \mathrm{~h}$ treatment with the concentrations of 500,1000, and $2000 \mu \mathrm{g} \cdot \mathrm{mL}^{-1}$ of the polyphenolic extract, respectively, in MKN45 cells. Cytarabine, a chemotherapeutic drug, at concentrations of 500,1000 , and $2000 \mu \mathrm{g} \cdot \mathrm{mL}^{-1}$ inhibited the growth of MKN45 cells by 87,82 , and $71 \%$, respectively. Interestingly, a combination of therapy with olive extract and drug (Fig. 1A-C) further decreased the viability of the cells by $60 \%, 55 \%$, and $54 \%$ for 500, 1000, and $2000 \mu \mathrm{g} \cdot \mathrm{mL}^{-1}$ concentrations after 24 $h$, respectively. These anti-cancer effects of the extract (alone or in combination with the drug) were further increased after $48 \mathrm{~h}$ and $72 \mathrm{~h}$ (Fig. 1B and C). To investigate the effects of extract on normal cells, we selected human foreskin fibroblast Hu02 cells. Notably, low concentrations (500 and $1000 \mu \mathrm{g} \cdot \mathrm{mL}^{-1}$ ) of the olive 
extract, Cytarabine and their combinations showed no significant effect on the viability of the normal $\mathrm{Hu} 02$ cells after 24 and $48 \mathrm{~h}$ (Fig. 1D and E). A marginal decrease in the viability of the Hu02 was observed at $1000 \mu \mathrm{g} \cdot \mathrm{mL}^{-1}$ after a longer treatment time $(72 \mathrm{~h})$, suggesting that anti-cancer effects of low concentration of the olive extracts can be used for a selective targeting of the cancerous cells (Fig. 1F). However, similar to MKN45 cells, the high concentrations of extract (2000 $\left.\mu \mathrm{g} . \mathrm{mL}^{-1}\right)$, drug and their combinations showed a potent cell death induction in the normal cells (Fig. 1D-F).
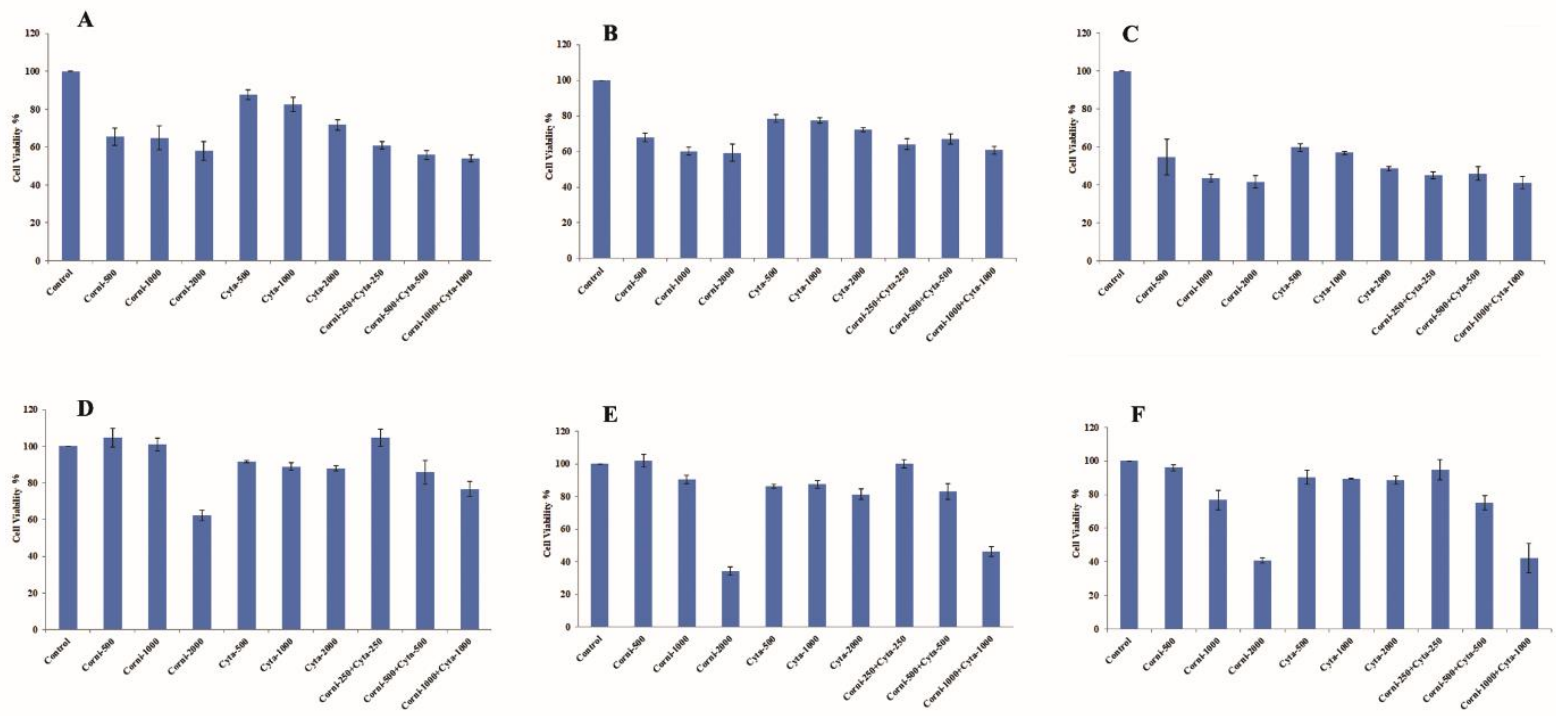

Figure 1. The effects of the total olive fruits polyphenolic extract (Corni) and its combination therapy with cytarabine on the viability of MKN45 (A, B, and C) and Hu02 (D, E and F) cells. The cells were treated with different concentrations of corni $\left(500,1000\right.$ and $\left.2000 \mu \mathrm{g} . \mathrm{mL}^{-1}\right)$ and cytarabine $(500$, 1000 and $\left.2000 \mu \mathrm{g} \cdot \mathrm{mL}^{-1}\right)$ as well as their combination therapies, then viability was determined after $24 \mathrm{~h}(\mathrm{~A}, \mathrm{D}), 48 \mathrm{~h}(\mathrm{~B}, \mathrm{E})$, and $72 \mathrm{~h}(\mathrm{C}, \mathrm{F})$ in both Cells. Results were reported as percent of control $(\%)$ and expressed as average \pm S.E. differences $(p<0.05)$ were considered statistically significant in comparison with the controls $\left(^{*}\right)$.

\subsection{Olive Fruits Extract Concentration and MKN45}

\section{Cell Death Morphological Signature}

To get more insight into the effects of olive extract, we studied the morphology of MKN45 cells following treatment with different concentrations of the polyphenol extracts (Fig. 2).

As can be observed in Fig 2 the typical signs of cell death (i.e. cell debris, aggregation, and shrinking) were detected in a concentration-dependent manner (Fig.
2A-F). In facts, the morphological changes corresponding to the cell death were clearly observed after incubation with 1000 and $2000 \mu \mathrm{g} \cdot \mathrm{mL}^{-1}$ concentrations of the extract (Fig. 2E and F). These results (Fig. 2) are in full agreement with the viability results observed in Figure 1.

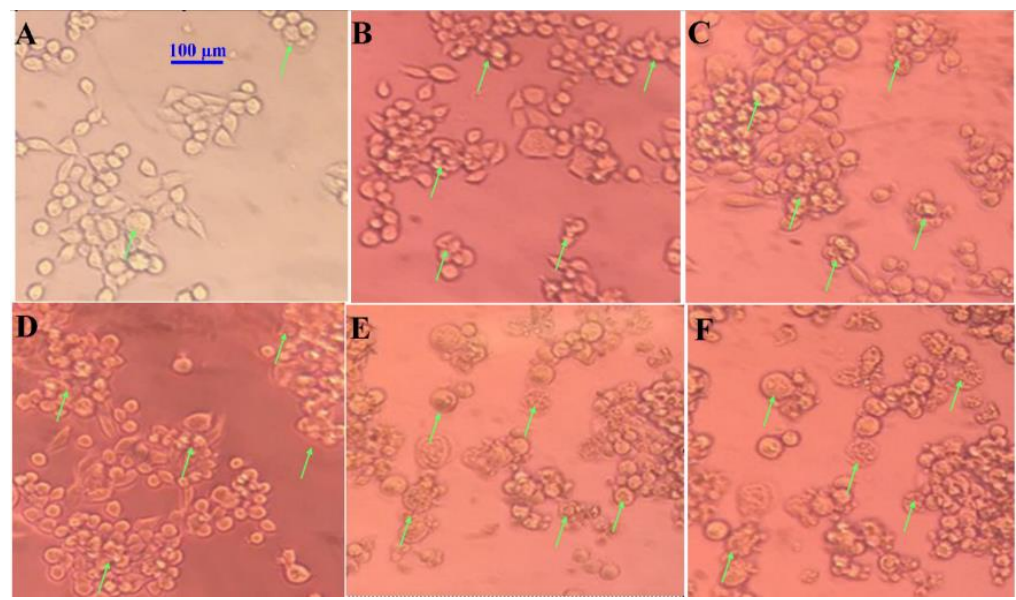

Figure 2. The morphological study of the MKN45 cells. non-treated group (A) and treated with 100 (B), 200 (C), 500 (D), 1000 (E) and 2000 (F) $\mu \mathrm{g} \cdot \mathrm{mL}^{-1}$ of cornicabra olive extracts after $24 \mathrm{~h}$. Arrows showed apoptotic cell death morphology. Scale bar represents $100 \mu \mathrm{m}$ in an invert light microscopy image. 
4.4. Effects of Olive Fruits Polyphenols, Alone or in Combination with Chemotherapy on MKN45 and $\mathrm{HuO2}$ Cells ROS Content

Since anti-cancer effects of the olive extracts are mediated through modulation of the oxidative stress status of the cells, we were also interested to study the effects of our system on ROS content of both normal $\mathrm{Hu} 02$ and cancerous MKN45 cells. As indicated in Figure 3 ROS generation was assayed at various concentrations of the extracts and different times (Fig. 3). Our results revealed that a significant decrease in the basic ROS level of the cancerous MKN45 cells was started after $6 \mathrm{~h}$ treatment with polyphenolic extract followed by a more reduction after $12 \mathrm{~h} \mathrm{(Fig.} 3 \mathrm{~A}$ and B). The effects of the extract on ROS level were different in the normal cells (Fig. 3C and D). While treatment of the $\mathrm{Hu} 02$ cells with different concentrations of the extract decreased ROS level after $6 \mathrm{~h}$, the total content of ROS started to increase after $12 \mathrm{~h}$ (Fig. $3 \mathrm{C}$ and D). To further study the anti-oxidant potential of the extract, we pretreated the cells with $\mathrm{H}_{2} \mathrm{O}_{2}$ and evaluated the effects of polyphenols on this strong pro-oxidant system. $\mathrm{H}_{2} \mathrm{O}_{2}$ at different concentrations $(25,50$ and $100 \mathrm{mM}$ ) showed strong ROS production and prooxidant effects in both cells (Fig. 3 ). Our results show that combination of olive extract substantially decreases ROS production by $\mathrm{H}_{2} \mathrm{O}_{2}$ in both cells. This effect was observed for all concentrations after 6 and $12 \mathrm{~h}$ incubation in both cells (Fig. 3). The effects of the extract in inhibiting the pro-oxidant potentials of $\mathrm{H}_{2} \mathrm{O}_{2}$ were higher in $\mathrm{Hu} 02$ cells than MKN45 cells.
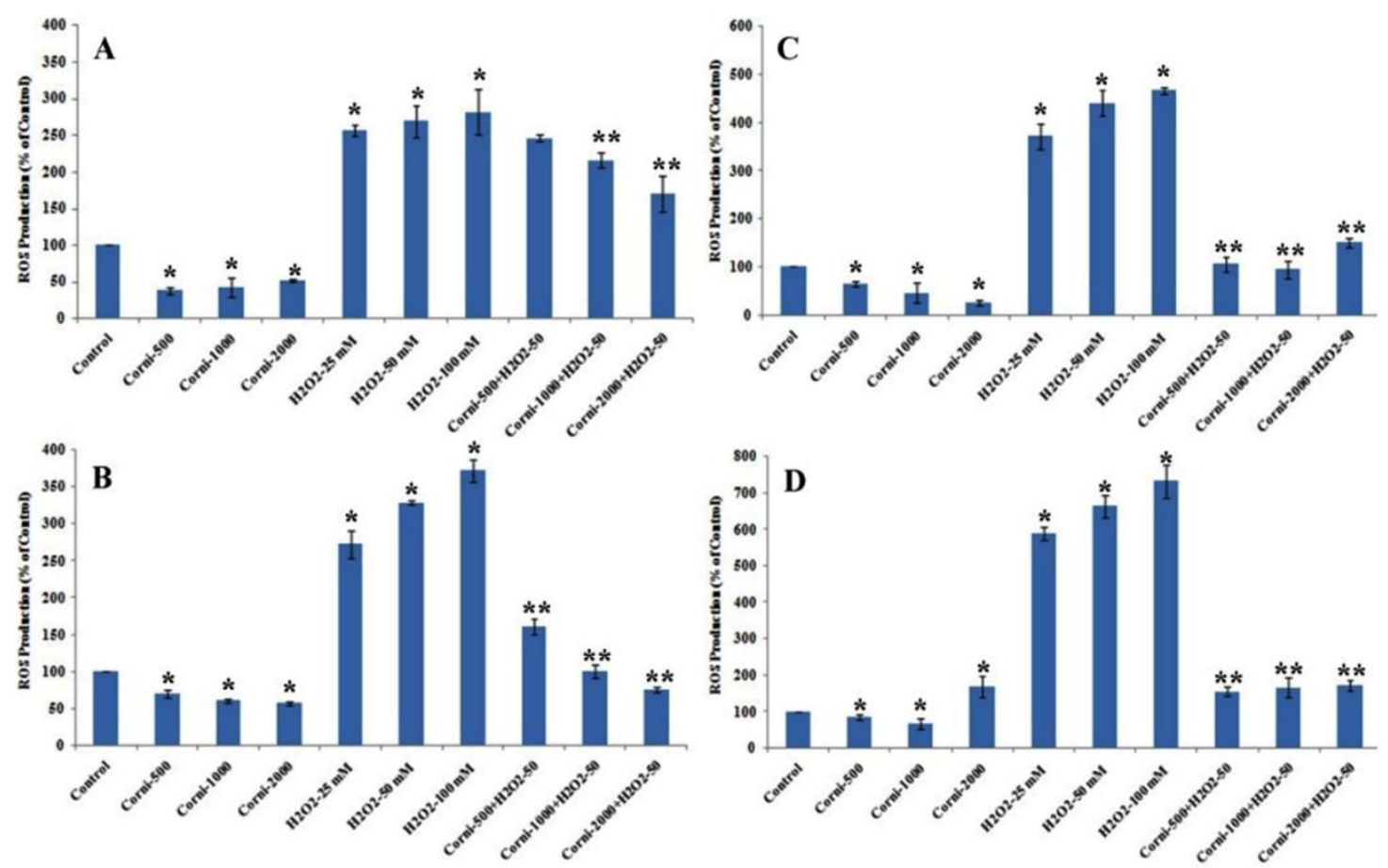

Figure 3. The effect of the total olive fruits polyphenolic extract on ROS production after $6 \mathrm{~h}(\mathrm{~A}$ and $\mathrm{C})$ and $12 \mathrm{~h}(\mathrm{~B}$ and $\mathrm{D})$ following treatment of the cancerous MKN45 cells (A and B), and normal Hu02 (C and D) cells, respectively. The effects of the olive extract on produced ROS by the different concentrations of $\mathrm{H}_{2} \mathrm{O}_{2}(25,50$, and $100 \mathrm{mM})$ were also studied. The total ROS levels were determined by detection with DCFH-DA fluorescence as mentioned in materials and methods. The significant difference $(\mathrm{P}<0.05)$ between the treated groups compared to the control groups are indicated with the asterisk $\left({ }^{*}\right)$. The ${ }^{* *}$ were used for showing the difference between the combination of $\mathrm{H}_{2} \mathrm{O}_{2}+$ extract compared to the $\mathrm{H}_{2} \mathrm{O}_{2}$ alone.

\section{Discussion}

Polyphenols are important classes of anti-oxidants in the olive oil (25). It has been evidenced that polyphenols of the olives act as anti-inflammatory components and can prevent cancer progression (26). Recent evidence showed that permanent of the olive oil consumption is associated with a lower risk of cancer development, especially in gastrointestinal cancers. Here, we reported for the first time that polyphenolic extracts of the olive fruits from the Cornicabra variety (this variety is cultivated in some region of Iran) can selectively target cancerous cells at both low concentrations and short treatment times. The morphological studies showed signs of cell death following treatment with different concentrations of the olive extract in cancerous cells (Fig. 2), while normal cells could survive at low concentrations treatment of the extracts (Fig. 1). Whether the mode of induced cell death is through apoptosis or other types of programmed cell death might be involved in this process need more investigation.

From a mechanistic viewpoint, it seems that Cornicabra olive extract manipulates the redox potential of the cells (Fig. 3). In fact, our used extracts have dramatically decreased ROS levels in MKN45 cells after $6 \mathrm{~h}$ and $12 \mathrm{~h}$ 
(Fig. 3A and B). These anti-oxidant effects of the extract were observed in the normal $\mathrm{Hu} 02$ cell (Fig. 3C and D), albeit at short times (6 h). After longer treatment times $(12 \mathrm{~h})$, the ROS level started to increase to the basic levels $\left(500\right.$ and $1000 \mu \mathrm{g} \cdot \mathrm{mL}^{-1}$ ) or even more $\left(2000 \mu \mathrm{g} \cdot \mathrm{mL}^{-1}\right)$. These different effects of the olive extract on ROS levels of the normal and cancerous cells can be related to the inherent differences between basic ROS levels and anti-oxidant defense systems of both cells $(27,28)$. In fact, it has been suggested that compared to the normal cells, cancerous cells are under a chronic oxidative stress and are more susceptible to the ROS manipulating strategies than normal cells $(29,30)$. It seems that anti-oxidative effects of the polyphenols can modulate oxidative stress-responsive genes, leading to the anti-cancer effects. In this condition, however, normal cells can survive because they have normally lower levels of ROS and harbor intact oxidative defense system (31). Recent reports indicated that treatment of cancerous cells with polyphenolic compounds of the olive oil leads to cell ROS modulation and consequently cell death $(32,33)$. Recently, it has been reported that cell proliferation is inhibited by some olive polyphenols in human HL60 cell line and colon cancer lines via ROS manipulation $(32,34)$.

Combination therapies with natural polyphenols and the known chemotherapeutic drugs could improve cancer treatment options. Interestingly, combining polyphenols with the conventional therapies might lead to overcoming drug resistance and reducing the side effects of the standard anti-cancer therapies. For instance, several studies have shown that a combination of resveratrol with quercetin or Curcumin has increased the growth inhibition effects compared with each monotherapy in oral squamous carcinoma and colon cancers, respectively (35). Menendez et al. have reported that the polyphenols in the extra virgin olive oil (EVOO) can diminish the acquired resistance to trastuzumab in HER2-overexpressing breast cancer cell lines through activation of the signaling pathways, inducing cell death, and cell cycle arrest in different tumor cell lines as well as their anti-oxidant and antiinflammatory abilities $(36,37)$. In line with the above reports, the results of this study show a higher anticancer effect for a combination of extract and cytarabine in comparison with each therapy alone. These results are in agreement with the recent reports concerning the additive effects of the extract of the different plants in growth inhibition of the human cancer models (38-40). Polyphenols are double-edged swords that show either beneficial effects at physiologic (low) doses or deleterious effects at pathologic (high) doses $(41,42)$. Our results showed that the treatment with extract decreased the pro-oxidant potential of $\mathrm{H}_{2} \mathrm{O}_{2}$ in both cancer and normal cell lines as determined by measuring ROS production (Fig. 3). These results fully confirm the anti-oxidant potential of our used extract in the cell culture system and suggest that increased levels of ROS can be scavenged by phenolic compounds. However, it should be mentioned that polyphenols can either scavenge ROS or paradoxically generate additional amounts of ROS to inhibit cancer cells proliferation. It has been observed that the low and high concentrations of the same polyphenolic compound are responsible for anti-oxidant and pro-oxidant activities, respectively (26, 42-45). Moreover, it should be considered that elevated levels of ROS in the cells might be a defensive mechanism to cope with the stress resulted from high dosage administration of the phenol extracts. Thus, further studies are required to elucidate the underlying molecular mechanisms of the olive extracts.

\section{Conclusions}

Cornicabra olive extract presents a potent inhibitory effect on ROS level and viability of the cancerous MKN45 cells. Accordingly, its combination with cytarabine could sensitize cancerous cells to the chemotherapy. Although olive extract manipulated ROS levels in $\mathrm{Hu} 02$ cells, the viability of these normal cells did not significantly change at low concentrations and short treatment times. Thus, Cornicabra polyphenols can selectively target cancerous cells and could be proposed as a candidate for combination therapy of cancer.

\section{Acknowledgments}

This work has been partially supported by the Center for International Scientific Studies \& Collaboration (CISSC), National Institute of Genetic Engineering and Biotechnology (NIGEB) and Stem Cell Technology Research Center of Iran.

\section{References}

1. Daayf F, Lattanzio V. Recent advances in polyphenol research: John Wiley \& Sons; 2008.

2. Salvini S, Sera F, Caruso D, Giovannelli L, Visioli F, Saieva $\mathrm{C}$, et al. Daily consumption of a high-phenol extra-virgin olive oil reduces oxidative DNA damage in postmenopausal women. Br J Nutr. 2006;95(4):742-751. doi: 10.1079/bjn20051674 pmid: 16571154

3. Visioli F, Galli C. Biological properties of olive oil phytochemicals. Crit Rev Food Sci Nutr. 2002;42(3):209221. doi: 10.1080/10408690290825 529 pmid: 12058980

4. Sofi F, Abbate R, Gensini GF, Casini A. Accruing evidence on benefits of adherence to the Mediterranean diet on health: an updated systematic review and meta-analysis. Am J Clin Nutr. 2010;92(5):1189-1196. doi: 10.3945/ajcn.2010.29673 pmid: 20810976

5. Hoffmann G, Schwingshackl L. Mediterranean diet supplemented with extra virgin olive oil reduces the incidence of invasive breast cancer in a randomised controlled trial. Evid Based Med. 2016;21(2):72. doi: 10.1136/ebmed-2015-110366 pmid: 26744413

6. Menendez JA, Vazquez-Martin A, Oliveras-Ferraros C, Garcia-Villalba R, Carrasco-Pancorbo A, FernandezGutierrez A, et al. Extra-virgin olive oil polyphenols inhibit HER2 (erbB-2)-induced malignant transformation in 
human breast epithelial cells: relationship between the chemical structures of extra-virgin olive oil secoiridoids and lignans and their inhibitory activities on the tyrosine kinase activity of HER2. Int J Oncol. 2009;34(1):43-51. doi: 10.3892/ijo_00000127 pmid: 19082476

7. Lopez-Miranda J, Perez-Jimenez F, Ros E, De Caterina R, Badimon L, Covas MI, et al. Olive oil and health: summary of the II international conference on olive oil and health consensus report, Jaen and Cordoba (Spain) 2008. Nutr Metab Cardiovasc Dis. 2010;20(4):284-294. doi: 10.1016/j.numecd.2009.12.007 pmid: 20303720

8. Khan N, Afaq F, Mukhtar H. Apoptosis by dietary factors: the suicide solution for delaying cancer growth. Carcinogenesis. 2007;28(2):233-239. doi: 10.1093/carc in/bgl243 pmid: 17151090

9. Porrini M, Riso P, Brusamolino A, Berti C, Guarnieri S, Visioli F. Daily intake of a formulated tomato drink affects carotenoid plasma and lymphocyte concentrations and improves cellular antioxidant protection. $\mathrm{Br} J$ Nutr. 2005;93(1):93-99. doi: 10.1079/bjn20041315 pmid: 15705230

10. Rahman I, Biswas SK, Kirkham PA. Regulation of inflammation and redox signaling by dietary polyphenols. Biochem Pharmacol. 2006;72(11):1439-1452. doi: 10.1016/j.bcp.2006.07.004 pmid: 16920072

11. Moosavi MA, Sharifi M, Ghafary SM, Mohammadalipour $\mathrm{Z}$, Khataee A, Rahmati M, et al. Photodynamic N-TiO2 Nanoparticle Treatment Induces Controlled ROSmediated Autophagy and Terminal Differentiation of Leukemia Cells. Sci Rep. 2016;6(1):34413. doi: 10.1038/srep34413 pmid: 27698385

12. Chen ZP, Schell JB, Ho CT, Chen KY. Green tea epigallocatechin gallate shows a pronounced growth inhibitory effect on cancerous cells but not on their normal counterparts. Cancer Lett. 1998;129(2):173-179. doi: 10.1016/s0304-3835(98)00108-6 pmid: 9719459

13. Pan MH, Lai CS, Hsu PC, Wang YJ. Acacetin induces apoptosis in human gastric carcinoma cells accompanied by activation of caspase cascades and production of reactive oxygen species. $J$ Agric Food Chem. 2005;53(3):620-630. doi: 10.1021/jf048430m pmid: 15686411

14. Mousavi SM, Gouya MM, Ramazani R, Davanlou M, Hajsadeghi N, Seddighi Z. Cancer incidence and mortality in Iran. Ann Oncol. 2009;20(3):556-563. doi: 10.1093/annonc/mdn642 pmid: 19073863

15. Ferlay J, Shin HR, Bray F, Forman D, Mathers C, Parkin DM. Estimates of worldwide burden of cancer in 2008: GLOBOCAN 2008. Int J Cancer. 2010;127(12):28932917. doi: $10.1002 /$ ijc. 25516 pmid: 21351269

16. Torre LA, Siegel RL, Ward EM, Jemal A. Global Cancer Incidence and Mortality Rates and Trends--An Update. Cancer Epidemiol Biomarkers Prev. 2016;25(1):16-27. doi: 10.1158/1055-9965.EPI-15-0578 pmid: 26667886

17. Almasi Z, Rafiemanesh H, Salehiniya H. Epidemiology characteristics and trends of incidence and morphology of stomach cancer in Iran. Asian Pac J Cancer Prev. 2015;16(7):2757-2761. doi: 10.7314/apjcp.2015.16.7 .2757 pmid: 25854359

18. Salvador MD, Aranda F, Gómez-Alonso S, Fregapane G. Cornicabra virgin olive oil: a study of five crop seasons. Composition, quality and oxidative stability. Food Chem 2001;74(3):267-274. doi: 10.1016/s03088146(01)00148-0
19. Singleton VL, Orthofer R, Lamuela-Raventós RM. [14] Analysis of total phenols and other oxidation substrates and antioxidants by means of folin-ciocalteu reagent. Methods in enzymology. 299: Academic press; 1999. p. 152-178.

20. Brand-Williams W, Cuvelier ME, Berset C. Use of a free radical method to evaluate antioxidant activity. $L W T$ Food Sci Technol 1995;28(1):25-30. doi: 10.1016/s00236438(95)80008-5

21. Benavente-García O, Castillo J, Lorente J, Ortuño A, Del Rio JA. Antioxidant activity of phenolics extracted from Olea europaea L. leaves. Food Chem 2000;68(4):457-462. doi: 10.1016/s0308-8146(99)0 0221-6

22. Kalyanaraman B, Darley-Usmar V, Davies KJ, Dennery $\mathrm{PA}$, Forman HJ, Grisham MB, et al. Measuring reactive oxygen and nitrogen species with fluorescent probes: challenges and limitations. Free Radic Biol Med. 2012;52(1):1-6. doi: 10.1016/j.freeradbiomed.201 1.09.030 pmid: 22027063

23. Alfadda AA, Sallam RM. Reactive oxygen species in health and disease. J Biomed Biotechnol. 2012;2012:936486. doi: 10.1155/2012/936486 pmid: 22927725

24. Wittmann C, Chockley P, Singh SK, Pase L, Lieschke GJ, Grabher C. Hydrogen peroxide in inflammation: messenger, guide, and assassin. Adv Hematol. 2012;2012:541471. doi: $10.1155 / 2012 / 541471$ pmid: 22737171

25. Vauzour D, Rodriguez-Mateos A, Corona G, OrunaConcha MJ, Spencer JP. Polyphenols and human health: prevention of disease and mechanisms of action. Nutrients. 2010;2(11):1106-1131. doi: 10.3390/nu2 111106 pmid: 22254000

26. Scalbert A, Manach C, Morand C, Remesy C, Jimenez L. Dietary polyphenols and the prevention of diseases. Crit Rev Food Sci Nutr. 2005;45(4):287-306. doi: 10.1080/1040869059096 pmid: 16047496

27. Nechifor M, Neagu T-M, Manda G. Reactive Oxygen Species, Cancer and Anti-Cancer Therapies. Curr Chem Biol 2009;3(1):22-46. doi: 10.2174/22127968109030 10022

28. Gorrini C, Harris IS, Mak TW. Modulation of oxidative stress as an anticancer strategy. Nat Rev Drug Discov. 2013;12(12):931-947. doi: $10.1038 / \mathrm{nrd} 4002$ pmid: 24287781

29. Trachootham D, Alexandre J, Huang P. Targeting cancer cells by ROS-mediated mechanisms: a radical therapeutic approach? Nat Rev Drug Discov. 2009;8(7):579-591. doi: 10.1038/nrd2803 pmid: 19478820

30. Ziech D, Franco R, Georgakilas AG, Georgakila S, Malamou-Mitsi V, Schoneveld O, et al. The role of reactive oxygen species and oxidative stress in environmental carcinogenesis and biomarker development. Chem Biol Interact. 2010;188(2):334-339. doi: 10.1016/j.cbi.2010.07.010 pmid: 20637748

31. Chan MM, Soprano KJ, Weinstein K, Fong D. Epigallocatechin-3-gallate delivers hydrogen peroxide to induce death of ovarian cancer cells and enhances their cisplatin susceptibility. J Cell Physiol. 2006;207(2):389396. doi: 10.1002/jcp.20569 pmid: 16402374

32. Hashim YZ, Rowland IR, McGlynn H, Servili M, Selvaggini R, Taticchi A, et al. Inhibitory effects of olive oil phenolics on invasion in human colon adenocarcinoma cells in vitro. Int J Cancer. 2008;122(3):495-500. doi: 10.1002/ijc.23148 pmid: 17943720 
33. Owen RW, Giacosa A, Hull WE, Haubner R, Wurtele G, Spiegelhalder B, et al. Olive-oil consumption and health: the possible role of antioxidants. Lancet Oncol. 2000;1(2):107-112. doi: 10.1016/s14702045(00)00015-2 pmid: 11905662

34. Corona G, Deiana M, Incani A, Vauzour D, Dessi MA, Spencer JP. Hydroxytyrosol inhibits the proliferation of human colon adenocarcinoma cells through inhibition of ERK1/2 and cyclin D1. Mol Nutr Food Res. 2009;53(7):897-903. doi: 10.1002/mnfr.200800269 pmid: 19685549

35. Majumdar AP, Banerjee S, Nautiyal J, Patel BB, Patel V, $\mathrm{Du} J$, et al. Curcumin synergizes with resveratrol to inhibit colon cancer. Nutr Cancer. 2009;61(4):544-553. doi: 10.1080/01635580902752262 pmid: 19838927

36. Bouallagui Z, Han J, Isoda H, Sayadi S. Hydroxytyrosol rich extract from olive leaves modulates cell cycle progression in MCF-7 human breast cancer cells. Food Chem Toxicol. 2011;49(1):179-184. doi: 10.1016/j.fct.2010.10.014 pmid: 20955751

37. Sirianni R, Chimento A, De Luca A, Casaburi I, Rizza P, Onofrio A, et al. Oleuropein and hydroxytyrosol inhibit MCF-7 breast cancer cell proliferation interfering with ERK1/2 activation. Mol Nutr Food Res. 2010;54(6):833840. doi: 10.1002/mnfr.200900111 pmid: 20013881

38. Stearns ME, Amatangelo MD, Varma D, Sell C, Goodyear SM. Combination therapy with epigallocatechin-3-gallate and doxorubicin in human prostate tumor modeling studies: inhibition of metastatic tumor growth in severe combined immunodeficiency mice. Am J Pathol. 2010;177(6):3169-3179. doi: 10.2353/ajpath.2010. 100330 pmid: 20971741
39. Chen L, Ye HL, Zhang G, Yao WM, Chen XZ, Zhang FC, et al. Autophagy inhibition contributes to the synergistic interaction between EGCG and doxorubicin to kill the hepatoma Hep3B cells. PLoS One. 2014;9(1):e85771. doi: 10.1371/journal.pone.0085 771 pmid: 24465696

40. Lev-Ari S, Zinger H, Kazanov D, Yona D, Ben-Yosef R, Starr A, et al. Curcumin synergistically potentiates the growth inhibitory and pro-apoptotic effects of celecoxib in pancreatic adenocarcinoma cells. Biomed Pharmacother. 2005;59 Suppl 2:S276-280. doi: 10.1016/s07533322(05)80045-9 pmid: 16507392

41. Mileo AM, Miccadei S. Polyphenols as Modulator of Oxidative Stress in Cancer Disease: New Therapeutic Strategies. Oxid Med Cell Longev. 2016;2016:6475624. doi: $10.1155 / 2016 / 6475624$ pmid: 26649142

42. Martin KR. Polyphenols as dietary supplements: A double-edged sword. Nutr Diet Supple 2009:1. doi: $10.2147 /$ nds.s6422

43. Goya L, Mateos R, Bravo L. Effect of the olive oil phenol hydroxytyrosol on human hepatoma HepG2 cells. Protection against oxidative stress induced by tertbutylhydroperoxide. Eur J Nutr. 2007;46(2):70-78. doi: 10.1007/s00394-006-0633-8 pmid: 17200875

44. Paiva-Martins F, Fernandes J, Rocha S, Nascimento H, Vitorino R, Amado F, et al. Effects of olive oil polyphenols on erythrocyte oxidative damage. Mol Nutr Food Res. 2009;53(5):609-616. doi: 10.1002/mnfr.20 0800276 pmid: 19340892

45. Rice-Evans CA, Miller NJ, Bolwell PG, Bramley PM, Pridham JB. The relative antioxidant activities of plantderived polyphenolic flavonoids. Free Radic Res. 1995;22(4):375-383. doi: 10.3109/10715769509145 649 pmid: 7633567 